\title{
Russell Wills
}

\section{Has Budget 2015 Solved Child}

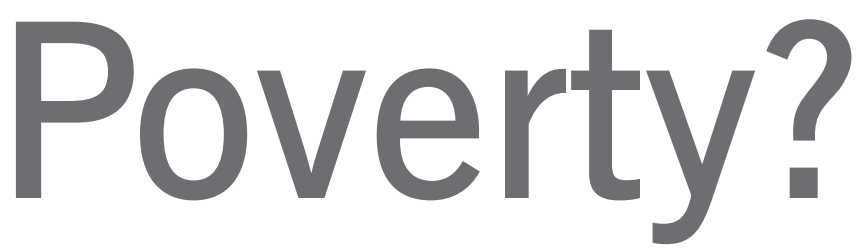

The New Zealand public spoke and the pollsters listened: child poverty consistently ranks among the top concerns of New Zealanders (Levine, 2014). And the prime minister listened too. In September 2014, after securing a healthy election victory, he proclaimed that he was going to step in and tackle child poverty (Fox, 2014). The policy analysts in a range of government agencies were set a task: come up with a package for Budget 2015 that helps children in poverty, that doesn't cost too much and that won't reduce the incentive to work.

This article will demonstrate that the policy analysts did the best they could with the brief they were given. However, because the brief from ministers was

narrow, the impact will be limited. The job of reducing child poverty in New Zealand is far from over.

Russell Wills is the New Zealand Children's Commissioner, and has made addressing child poverty one of the priorities of his term as commissioner. He is also a practising paediatrician.
Child poverty is a wicked policy problem

Wicked problems (Briggs, 2007) are typically difficult to solve due to incomplete or contradictory knowledge, the number of people and opinions involved, the large economic burden, and their interconnectedness with other problems.

The facts of child poverty in New Zealand are well traversed in Solutions to Child Poverty in New Zealand: evidence for action (Expert Advisory Group, 2012) and Child Poverty in New Zealand (Boston and Chapple, 2014). The synopsis is that, regardless of the measure used, child poverty is high relative to past levels, all other age groups, and most other developed countries. According to the Child Poverty Monitor, as many as $24 \%$ of children in New Zealand $(260,000)$ live in income poverty and 17\% (180,000 children) experience material hardship (Child Poverty Monitor, 2014). Figure 1 shows income poverty trends by age group over the past three decades.

As with all wicked problems, there is no single solution. All evidence shows that significant and durable reductions 
Figure 1: Income poverty trends by age groups

Proportions of population living below the $60 \%$ income poverty threshold (after housing costs) by select age-group, New Zealand - 1982-2013 HES years

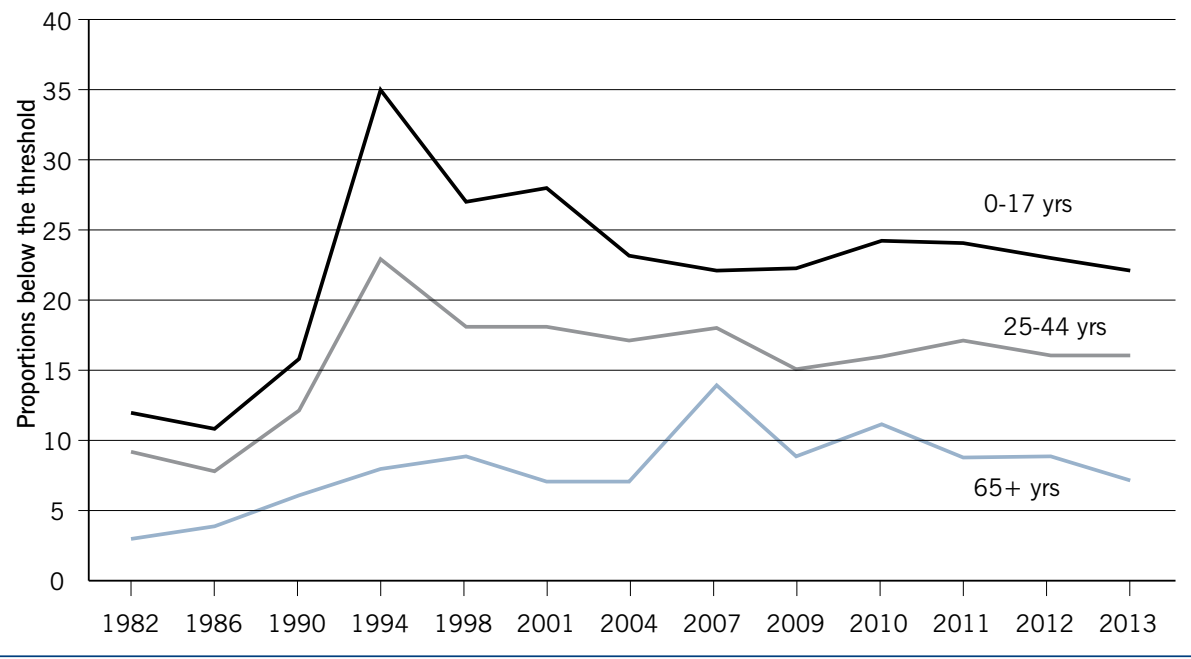

Source: Derived from Perry (2014)

Table 1: Material hardship - number of items that a family lacks out of 17 items

\begin{tabular}{lllllll}
\hline Dep-17 score & $6+$ & $7+$ & $8+$ & $9+$ & $10+$ & $11+$ \\
\hline All ages (\%) & 14 & 11 & 8 & 6 & 4 & 3 \\
0-17 years (\%) & 21 & 17 & 13 & 10 & 8 & 6 \\
\hline \# of children (000) & 220 & 180 & 140 & 100 & 80 & 60 \\
\hline
\end{tabular}

Source: Perry (2015)

in child poverty take time and money. Actions are required to address a range of interrelated areas, including:

- affordable, safe, healthy homes;

- stable, nurturing families;

- supportive communities;

- adequate income to meet needs;

- a supportive education sector; and

- accessible health services.

Responsibility for addressing child poverty is a shared responsibility between parents, wider family members, communities, non-governmental organisations and government alike. The package of support included in Budget 2015 is focused on one aspect of child poverty: adequate income.

\section{What did the government ask of policy analysts?}

The regulatory impact statement (RIS) ${ }^{1}$ prepared by the responsible agencies noted that the government's objective for this package of changes was:

to take immediate action to reduce material hardship amongst children, particularly those living in deeper levels of material deprivation, while taking into account:
- supporting financial incentives and workforce attachment for households with children;

- supporting children's development;

- managing fiscal costs and ensuring value for money for tax payers. (Department of the Prime Minister and Cabinet, Ministry of Social Development and Treasury, 2015, p.14)

Within this framework, analysts used the following criteria to assess options:

- effectiveness of targeting;

- impact on work incentives/ employment outcomes;

- timeliness (that the package could be implemented within a year of Budget 2015);

- level of administrative complexity;

- costs to not exceed NZ\$250m per year; and

- not cutting across existing work streams.

Policy options were developed which canvassed a range of possible levers, including the family tax credit, accommodation supplement, benefit rates and the in-work tax credit.
So what did Budget 2015 deliver for child poverty?

\section{Renaming the problem}

The first thing to notice about the Budget 2015 package is that the aim of the government has shifted from 'tackling child poverty' to 'providing some support to children living in severe material hardship'. This new discussion of severe material hardship required a new set of measures and thresholds. The Ministry of Social Development stepped into the breach by deconstructing the current Material Wellbeing Index (MWI) and using core elements to develop a 17-item deprivation index, aptly named Dep-17 (Perry, 2015). The Dep-17 provides a simpler and more intuitive way of communicating hardship when focusing on those at the low end of the MWI living standards scale. The MWI surveys essential items families regularly do without or have recently done without due to unaffordability. The 17 items include postponing visit to the doctor, putting up with feeling cold, having two pairs of shoes, and meals with meat (or other protein).

According to the MWI, $17 \%$ of children, or 180,000, are living in material hardship, defined as missing out on seven or more of the 17 items on the Dep-17. Perry suggests that the 'more severe hardship zone' be defined as those missing out on nine or more items (Perry, 2015, p.17). As shown in Table 1, this would mean $10 \%$ of New Zealand children (100,000 children) are living in severe material hardship. The table makes it clear that where we draw the line to define 'severe' hardship is arbitrary.

\section{Budget 2015 package}

The substantial elements ${ }^{2}$ of the child hardship package in Budget 2015 include:

- an increase in the benefit rate for families with children by $\$ 25$ per week;

- an increase in the maximum rate of the Working for Families (WFF) in-work tax credit by $\$ 12.50$ per week;

- an increase in the abatement rate for WFF tax credits by 1.25 percentage points; 
- an increase in child care assistance by \$1 per hour for the poorest working families;

- increases in work availability obligations for beneficiary parents that:

- lower the age of the youngest child at which part-time work search obligations begin (from age 5 to 3 years);

- increase the hours of part-time work sought from 15 to 20 hours a week;

- add a new requirement for sole parent support recipients to reapply for the benefit and reconfirm eligibility on an annual basis.

The total value of the package is $\$ 790$ million over four years, with an estimated ongoing cost of $\$ 237$ million per year from $2018-19 .^{3}$

What will this package mean for children? The regulatory impact statement shows the complexity of modelling and analysis required to design, effectively target, and monitor the impact and costs of changes to the benefit and income support systems and subsidies. The modelling provided in the RIS demonstrates aggregate increases for families with children ranging from $\$ 17.50$ to $\$ 49.58$ per week, depending on income source, number of hours worked, ages of children and accommodation type. The greatest increases were for a couple with four children, receiving child care support and working 40 and 20 hours (\$49.58); and a sole parent with two children, receiving child care support and working 30 hours (\$44.90).

The aggregate gains appear to meet the policy objectives in that incomes are increased, increases are largely targeted to those in greater need, and child care costs (noted as a barrier to re-entry to work) are reduced. The public servants did their job well. The package achieved the policy objectives they were given. My concern is that the objectives set by ministers were too limiting to make the difference that children need.

Increases to the benefit rate

The gap between market and benefit incomes has steadily grown over the past three decades, because benefit incomes are not indexed to the median wage and the tax system has become less progressive. This has been well documented in the OECD's recent economic survey of New Zealand (OECD, 2015). Overall, the increase in benefit rates accounts for just over half the value of the total package. It is pleasing to see an increase in benefit rates (especially as this is the first increase in benefit rates in over 40 years). A further step of indexing these rates to a proportion of the growth in the median wage would lock in that change; without indexing rates to the median wage - as national superannuation is indexed - the gains will inevitably be eroded over time. Why would we index a benefit for older impact of the abatement will be greater in dollar terms than the increase in the inwork tax credit, so these families will be worse off due to the combined changes.

Millions of dollars in savings will be generated through the increased abatement, and used to offset the increase in the maximum in-work tax credit. Increasing the abatement rate is effectively a redistribution of income from families with moderate-to-low incomes to families with very low incomes. The amount of this saving was not set out separately in the RIS.

Increase to child care assistance for some families

Currently, child care assistance is available

\section{Children living in hardship in larger families, where poverty is more prevalent, will see less effect from these changes.}

people to the median wage but not do this for children?

A weekly rise in benefits of up to $\$ 25$ for families in greatest need will be helpful for a family with one child, though less so for those with more children, as the increase is per family, rather than per child. Children living in hardship in larger families, where poverty is more prevalent, will see less effect from these changes.

\section{Increase of the in-work tax credit and WFF} abatement rate

Increasing the maximum in-work tax credit by $\$ 12.50$ per week will be helpful for children in working families on very low to moderate incomes. Again, the impact for a child living in a larger family, where poverty is more prevalent, will be relatively small. The WFF abatement is the rate at which the WFF payment decreases as income increases above a designated threshold. Increasing the abatement rate means families with incomes over $\$ 36,350$ will have tax credits reduced more quickly. For families with incomes over $\$ 88,000$ the for families on low incomes, with a maximum subsidy of $\$ 4$ per hour per child. The change will add a new category for the poorest working families, with a higher subsidy of $\$ 5$ per hour for families with one child and gross weekly income below $\$ 800$. This tightly targeted element of the Budget package accounts for more than $\$ 100$ million of new investment over four years and will benefit approximately 18,000 low-income working families by an average of \$22.96 per week. Considering the increased obligations to work, additional child care support is certainly warranted. The cost of quality child care continues to be a barrier for many families entering and sustaining employment.

\section{Work obligations}

International research indicates that a parent obtaining paid employment with sufficient earnings can be a powerful and effective way to lift children out of poverty. However, an adequate safety net is also required for those who are unable to work and to acknowledge the impact 
of economic conditions where jobs are scarce. This is particularly true for sole parents, as they face considerable challenges in supporting their children through paid employment and meeting their child care needs (Garden, 2014).

Gaining appropriate, sustainable employment simply will not be achievable for some families. If the jobs do exist, employment needs to be family-friendly, with hours of work coinciding with availability and affordability of good quality child care. Placing more work obligations on beneficiaries may not necessarily result in any more parents moving into employment, but it will put added pressure and compliance obligations on those already in stressful sufficient to overcome the many complex issues they face. Therefore, the overall impact on alleviating hardship of this proposed package is likely to be small.

The RIS notes that it is difficult to calculate what impact the package will have on material hardship. Nevertheless, officials indicated that, as a rough estimate, the number of children in severe hardship was likely to fall by around $10 \%$ - from 100,000 to 90,000 - and that the depth of hardship on others will be alleviated. We will need to watch for improvements to child poverty measures, including the new DEP-17, to see if any changes are apparent from 2017-18 onward. The measure of success of this package to address child material hardship, therefore,

\section{The current ad hoc and complex system produces perverse and unintended consequences that excellent policy work can only partly address.}

circumstances. It will also cost the taxpayer more. More than $\$ 22$ million of the Budget 2015 package is allocated to increased implementation costs for the Ministry of Social Development associated with managing the additional work obligations and the re-application requirement.

What difference will these measures make? There is no doubt that having extra resources available in very low income families (whether that is from a benefit rate increase, in-work tax credit increases or higher child care subsidy) will be a welcome support to those families. It will likely reduce the poverty gap by lifting those at the very bottom of the income scale, but the increase will not be sufficient to lift many of these families out of poverty on any of the widely used income-based or hardship measures. This simply reflects the fact that the gap is very wide and will take more time and resources to narrow. Moreover, while increased income is important, for some of the neediest families it will not be is whether it can reduce the numbers of children in hardship over time.

What is missing in this package?

\section{Comprehensive system review}

Family income, and therefore child material hardship, is directly influenced by government policy on tax and income support. Getting that system performing well is critical if child poverty is to be reduced. Relevant parts of the tax and benefit systems include parents' employment earnings, WFF tax credits, benefit support, and other subsidies such as housing and child care assistance. The Budget 2015 package of changes to address child material hardship addressed some parts of the system. However, it fell well short of the independent and comprehensive review of all child-related benefit rates and relativities recommended by the expert advisory group (Expert Advisory Group, 2012).

The current ad hoc and complex system produces perverse and unintended consequences that excellent policy work can only partly address. For example, the package generates a saving of $\$ 23$ million over four years to the income-related rent subsidy. This is because giving an income increase to families in social housing also effectively increases the rent they are required to pay. Plus, we know that some families on low incomes are actually worse off as a result of the flow-on impacts of the changes: for example, losing more in the WFF abatement increase than they gain from the in-work tax credit increase. Including a top-up payment provision in the package for 'unintended losers' just adds another ad hoc fix to a patchedtogether system.

\section{An overall plan}

The investment in narrowing the gap between very low incomes and most widely accepted poverty thresholds is welcome and will be helpful for many families. It is positive that the government has recognised that the gap has grown too wide and is materially affecting health and education outcomes for children. While welcome, however, these changes are not the same as a plan to reduce child poverty over time. That is what we need. And while it is stated that the deeper causes and consequences of poverty and hardship (for example, in housing, cost of health care and education, parenting support) are to be addressed in other government work, we should expect to see this commitment explicitly outlined.

\section{Conclusion}

So, has child poverty been solved now, allowing government to move on to other issues? Not yet. Officials certainly can be given credit for fulfilling their brief, but the narrow focus of that brief means that the package announced in Budget 2015 will make only a small impact on child poverty.

I am pleased that the government has recognised that incomes for families with children matter by raising incomes for both beneficiary and working families. But wicked problems are not easy to solve. Addressing child poverty is going to need a longer-term approach, better planning and design, greater investment, and actions across a range of interrelated areas. Surely our children deserve nothing less. 
1 Regulatory impact statements are required alongside all major regulation, legislation or policy change to help ensure that the process is open and transparent. An RIS provides a high-level summary of the problem, the options and their associate costs and benefits, and the proposed arrangements for implementation (http://www.dpmc.govt.nz/sites/all/files/ publications/ris-budget15-cmh-may15.pdf).

2 There are other, lesser elements to address flow-on impacts, but these are not discussed here.

3 Unless otherwise stated, all figures are based on those reported in the RIS

\section{Acknowledgements}

I would like to thank Donna Provoost for her assistance with the preparation of this article.

\section{References}

Adams, J., M. Duncanson, G. Oben, A. Reddington, J. Simpson and A. Wicken (2014) Child Poverty Monitor 2014 Technical Report, Dunedin: New Zealand Child and Youth Epidemiology Service, University of Otago, retrieved from http://www.nzchildren.co.nz/ document_downloads/2014\%20Child\%20Poverty\%20Monitor\%20 Technical\%20Report.pdf

Boston, J. and S. Chapple (2014) Child Poverty in New Zealand, Wellington: Bridget Williams Books

Briggs, L. (2007) Tackling Wicked Problems: a public policy perspective, Canberra: Australian Public Service Commission, retrieved from http:// www.enablingchange.com.au/wickedproblems.pdf

Department of the Prime Minister and Cabinet, Ministry of Social Development and Treasury (2015) Regulatory Impact Statement: Budget 2015 package to address child material hardship in New Zealand, Wellington: DPMC, retrieved from http://www.dpmc.govt.nz/ sites/all/files/publications/ris-budget15-cmh-may15.pdf

Expert Advisory Group (2012) Solutions to Child Poverty in New Zealand: evidence for action, Wellington: Office of the Children's Commissioner, retrieved from http://www.occ.org.nz/assets/Uploads/EAG/Final-report/ Final-report-Solutions-to-child-poverty-evidence-for-action.pdf

Fox, M. (2014) 'Child poverty on Key agenda', stuff.co.nz, 24 September, http://www.stuff.co.nz/national/politics/10535794/Child-poverty-onKey-agenda
Garden, E. (2014) Speaking for Ourse/ves: the truth about what keeps people in poverty from those who live it, Auckland: Auckland City Mission, retrieved from http://www.aucklandcitymission.org.nz/ uploads/file/Family\%20100/City\%20Mission\%20Family100\%20 Speaking\%20for\%200urselves_website.pdf

Levine, M. (2014) Article no.5474 at Roy Morgan New Zealand, http:// s3.documentcloud.org/documents/1281236/roy-morgan-nz-issues.pdf OECD (2015) OECD Economic Surveys: New Zealand, retrieved from http://www.oecd.org/newzealand/economic-survey-new-zealand.htm

Perry, B. (2014) Household Incomes in New Zealand: trends in indicators of inequality and hardship 1982 to 2013, Wellington: Ministry of Social Development, retrieved from https://www.msd.govt.nz/aboutmsd-and-our-work/publications-resources/monitoring/householdincomes/

Perry, B. (2015) Measuring and Monitoring Material Hardship for New Zealand Children: MSD research and analysis used in advice for the Budget 2015 child hardship package, Wellington: Ministry of Social Development, retrieved from https://www.msd.govt.nz/documents/ about-msd-and-our-work/publications-resources/monitoring/childmaterial-hardship-2015.docx

\section{School of Government Te Kura Käwantanga

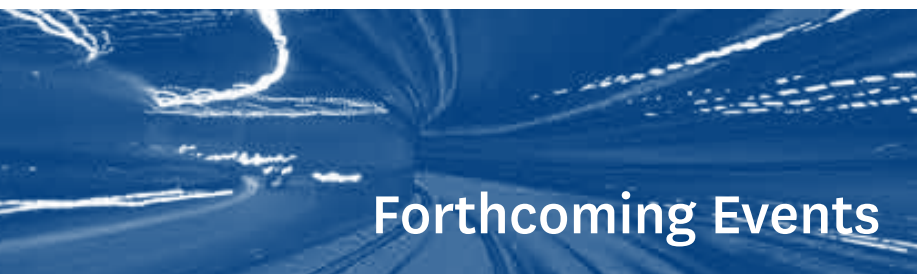

\begin{tabular}{llll} 
& Title & Speaker/Author & Date and Venue \\
\hline School of & The Public Sector Conference: & Register at & 16 September 2015 \\
Government with & Stewardship Today for the & publicsectorconference.org.nz & Intercontinental Hotel, Wellington \\
PSA, IPANZ, Skills & Generations of Tomorrow & &
\end{tabular}

\begin{tabular}{|c|c|c|c|}
\hline $\begin{array}{l}\text { Institute for } \\
\text { Governance and } \\
\text { Policy Studies }\end{array}$ & $\begin{array}{l}\text { NZ is Corruption-free - or is it? } \\
\text { Why do we need the Organised } \\
\text { Crimes and Anti-Corruption } \\
\text { Legislation Bill? }\end{array}$ & $\begin{array}{l}\text { Souella Cumming, } \\
\text { Fiona Tregonning }\end{array}$ & $\begin{array}{l}\text { Tue } 25 \text { Aug, 5:30-6:30pm } \\
\text { GBLT3, Government Buildings } \\
\text { Lecture Theatre } 3 \\
\text { RSVP igps@vuw.ac.nz }\end{array}$ \\
\hline $\begin{array}{l}\text { Health Services } \\
\text { Research Centre }\end{array}$ & $\begin{array}{l}\text { Investing for Success: Social } \\
\text { Impact Bonds and the future of } \\
\text { public services }\end{array}$ & $\begin{array}{l}\text { Jenesa Jeram, } \\
\text { Dr Bryce Wilkinson }\end{array}$ & $\begin{array}{l}\text { Wed } 2 \text { Sept 12:30-1:30pm } \\
\text { GBLT3, Government Buildings } \\
\text { Lecture Theatre } 3 \\
\text { RSVP not required }\end{array}$ \\
\hline $\begin{array}{l}\text { Health Services } \\
\text { Research Centre }\end{array}$ & $\begin{array}{l}\text { 20,000 Days and Beyond } \\
\text { Evaluation of CMDHB's Quality } \\
\text { Improvement Campaigns }\end{array}$ & $\begin{array}{l}\text { Lesley Middleton, Luis Villa, } \\
\text { David Mason, Jacqueline Cumming, } \\
\text { Janet McDonald }\end{array}$ & Report out now \\
\hline $\begin{array}{l}\text { Health Services } \\
\text { Research Centre }\end{array}$ & $\begin{array}{l}\text { Eldercare work, migrant care } \\
\text { workers, affective care and } \\
\text { subjective proximity }\end{array}$ & $\begin{array}{l}\text { Kirsten Lovelock, } \\
\text { Greg Martin }\end{array}$ & Forthcoming in Ethnicity \& Health \\
\hline
\end{tabular}

